\title{
Cytotoxic evaluation of essential oil from Casearia sylvestris Sw on human cancer cells and erythrocytes
}

\author{
Saulo Luís da SILVA ${ }^{1}$, Jamal da Silva CHAAR ${ }^{2}$, Patrícia de Maria Silva FIGUEIREDO ${ }^{3}$, Tomomasa YANO ${ }^{4}$
}

\begin{abstract}
Casearia sylvestris (Flacourtiaceae) is a plant popularly known as "guaçatonga" and it is used by indigenous population from South America (Brazil, Peru and Bolivia) in the treatment of several diseases, including cancer. Cytotoxic studies showed that it presents an interesting antitumoral potential due to the presence of casearins and the essential oil showed a high percentage of potent cytotoxic sesquiterpenes ( $\beta$-caryophyllene and $\alpha$-humulene). In this work, we verified that the essential oil of $C$. sylvestris presents a good selective cytotoxicity against HeLa, A-549 and HT-29 tumor cells $\left(\mathrm{CD}_{50} 63.3,60.7\right.$ and $90.6 \mu \mathrm{g} \cdot \mathrm{ml}^{-1}$, respectively) when compared to non-tumoral cells Vero $\left(\mathrm{CD}_{50} 210.1 \mu \mathrm{g} \cdot \mathrm{ml}^{-1}\right)$ and mice macrophages $\left(\mathrm{CD}_{50} 234.0 \mu \mathrm{g} \cdot \mathrm{ml}^{-1}\right)$. The oil causes hemolysis in seven different kinds of erythrocytes, indicating that $C$. sylvestris must be used carefully. Besides, standard of $\beta$-caryophyllene and $\alpha$-humulene were also tested and they showed similar cytotoxicity to the cytotoxicity presented in the oil, indicating that they might be responsible for the toxic effects that were observed in this study.
\end{abstract}

KEYWORDS: Cytotoxicity, Casearia sylvestris, Erythrocytes, Essential oil, MTT, Sesquiterpenes.

\section{Avaliação citotóxica do óleo essencial de Casearia sylvestris Sw sobre células tumorais humanas e eritrócitos}

\section{RESUMO}

A Casearia sylvestris (Flacourtiaceae) é uma planta popularmente conhecida como "guaçatonga" e é usada por povos indígenas da América do sul (Brasil, Peru e Bolivia) no tratamento de muitas doenças, incluindo câncer. Estudos citotóxicos mostraram que esta planta apresenta um possível e interessante potencial antitumoral devido à presença de moléculas chamadas casearinas. Além disso, a composição do óleo essencial mostrou uma alta concentração de sesquiterpenos de alto potencial citotóxico. Neste trabalho, nós verificamos que o óleo essencial da C. sylvestris apresentou uma boa citotoxicidade seletiva contra as linhagens de células tumorais HeLa, A-549 and HT-29 (CD 50 63,3, 60,7 e 90,6 $\mu \mathrm{g} \cdot \mathrm{ml}^{-1}$, respectivamente) quando comparada às células não-tumorais Vero $\left(\mathrm{CD}_{50} 210,1 \mu \mathrm{g} \cdot \mathrm{ml}^{-1}\right)$ e macrófagos de camundongos $\left(\mathrm{CD}_{50} 234,0 \mu \mathrm{g} \cdot \mathrm{ml}^{-1}\right)$. Além disso, o óleo causou hemólise em sete diferentes tipos de eritrócitos, indicando que a C. sylvestris precisa ser usada com cuidado. Também foram testados padrões de $\beta$-cariofileno e $\alpha$-humuleno que mostraram citotoxicidade similar àquelas apresentadas pelo óleo, indicando que estes compostos podem ser os responsáveis pelos efeitos tóxicos que foram observados neste estudo.

KEYwORDS: Citotoxicidade, Casearia sylvestris, Eritrócitos, Óleo essencial, MTT, Sesquiterpenos.

\footnotetext{
1 e-mail: biomol2@hotmail.com

2 Universidade Federal do Amazonas. e-mail: jchaar@ufam.edu.br

3 Universidade Estadual de Campinas. patty_marry@yahoo.com

${ }^{4}$ Universidade Estadual de Campinas. tyano@unicamp.br
} 


\section{INTRODUCTION}

Casearia sylvestris $\mathrm{Sw}$ (Flacourtiaceae) is a plant popularly known as "guaçatonga", "chá-de-bugre" or "cafezinho-domato" and it is geographically distributed throughout Latin America (Lorenzi \& Matos, 2002), also occurs in all extension of Brazilian territory (Felfili et al., 2002; Barbosa, et al., 2005; Hack, et al., 2005). The Karajá Indians from Brazilian prepare a maceration of this plant bark to treat diarrhoea and the Shipibo-Conibo Indians of Peru use a decoction of the bark for diarrhea, chest colds and flu. Other Indian tribes in Brazil smash the roots or seeds of guaçatonga to treat wounds and topical leprosy (Chiappeta, 1983; Taylor, 2002). The indigenous populations throughout the Amazon rainforest have used guaçatonga for a long time as a snakebite medicine (Ruppelt, 1991; Alves, 2000; Mors et al., 2000).

The literature have some studies that corroborate some medicinal properties of $C$. sylvestris as being anti-inflammatory (Raslan et al., 2002), antiulcerous (Basile et al., 1990; Esteves et al., 2005), anticancer (Morita et al., 1991; Mans et al., 2000) and antimicrobial (Da Silva, 2006). Nowadays, C. sylvestris is being used as an active principle in creams against herpes and it is also being commercialized in plants combinations used for make tea and infusions with phytotherapeutic purposes (Alves, 2000; Beutler et al., 2000; Menezes et al., 2004).

Mosaddik et al. (2004) showed the cytotoxic activity of C. Costulata, C. Grewiifolia, C. Grayi and C. Multinervosa on P388 lymphoblast cells of mouse. Orberlies et al. (2002) showed that alcohol extracts of $C$. sylvestris are cytotoxic against macrophages J774, however Maistro et al. (2004) showed that the alcohol extracts of $C$. sylvestris were not genotoxic against HTC (hepatoma tissue cells) and VT79 (Chinese hamster lung) cells.

Esteves et al. (2005) have determined recently the composition of the essential oil obtained from C. sylvestris leaves and verified that the major component is the bicyclogermacrene (40.9\%), a component with low antitumoral potential. Nevertheless, a high percentage of this essential oil (around 17.5\%) is constituted by two sesquiterpens, which cytotoxic activity is very potent and well characterized: $\beta$-caryophyllene (13.8\%) and $\alpha$-humulene (3.7\%) (Duh et al., 1999; Tatman et al., 2002; Sibanda et al., 2004; Sylvestre et al., 2005; Sylvestre et al., 2006; Hou et al. 2006; Xiao et al., 2006).

This work describes the evaluation of the $C$. sylvestris essential oil cytotoxity against tumor cells (HeLa, A-549 and HT-29 cell lines). In addition, to contribute to the safe usage of this plant as a phytopharmaco, the C. sylvestris leaves essential oil was tested against non tumoral cells (Vero cell, mice macrophages and seven different types of erythrocytes). Since the essential oil of this plant is rich in $\beta$-caryophyllene and $\alpha$-humulene (cytotoxic sesquiterpens against tumoral cells), the results obtained with $C$. sylvestris leaves essential oil were compared to the standards of these compounds that were also experimentally evaluated.

\section{MATERIAL AND METHODS}

\section{COLLECTION OF PLANT MATERIAL}

The fresh leaves of $C$. sylvestris were collected in Campinas city, S.P., Brazil, in 2005 March. The specimen was identified by Prof. A.M. Schimidel and a voucher was deposited under the number UEC 118743 in the herbarium of Unicamp Biological Institute.

\section{EXTRACTION OF THE ESSENTIAL OIL}

The essential oil was obtained from $750 \mathrm{~g}$ of leaves that were subdued to hydrodistillation for 4 hours in a modified Clevenger device resulting in a yellow essential oil (yield of $0.98 \%$ ). The oil was dried with anhydrous sodium sulphate and stored at $-20^{\circ} \mathrm{C}$ until use (Da Silva et al., 2006; Da Silva et al., 2007).

\section{OIL STANDARDIZATION BY GC-MS}

In order to characterize and standardize the essential oil, it was analyzed through gas chromatography (CG) with a Hewlett-Packard (HP) instrument model 5890 equipped with a flame ionization detector (FID) and a SE-54 glass column $(25 \mathrm{~m} \times 0.25 \mathrm{~mm}$ i.d., film thickness $0.25 \mu \mathrm{m})$. The carrier gas was helium at $1.0 \mathrm{ml} \cdot \mathrm{min}^{-1}$. The oven temperature was programmed from 50 to $250^{\circ} \mathrm{C}$ at $4^{\circ} \mathrm{C} / \mathrm{min}$ rate. Injector and interface temperatures were 220 and $250^{\circ} \mathrm{C}$. Gas chromatography-mass spectrometry (GC-MS) analyses were performed by using a Hewlett-Packard model 5880 (quadruple analyzer), operated in the electron impact mode $(70 \mathrm{eV})$, coupled to a Hewlett-Packard mass spectrometer model 5897A. High purity helium was used as carrier gas at a linear velocity of $1 \mathrm{ml} \cdot \mathrm{min}^{-1}$. The temperature conditions were the same used at CG analysis. The retention indexes (RI) were calculated through the Kovats index. In this determination was utilized a mixture of alkane standards $\mathrm{C}_{8}-\mathrm{C}_{16}$ additioned to the essential oils solution, and injected in the gas chromatograph in the same conditions of the chromatographic analysis. The identifications were carried out by comparison with MS literature data and by comparison of their RI values with those of pure standards and confirmed with the aid of RI from published sources whenever necessary (Davies, 1990; Massada, 1995; Adams, 1995).

\section{SESQUITERPENES STANDARDS TESTED}

The standards of $\beta$-caryophyllene and $\alpha$-humulene used in the comparison of the cytotoxic activity of the C. sylvestris leaves essential oil were supplied by Sigma (Co St. Louis, $\mathrm{MO})$. 


\section{CELL CULTURE}

HeLa cell lines (human cervical carcinoma), A-549 (human lung carcinoma), HT-29 (human colon adenocarcinoma) and Vero (monkey kidney) were obtained from the American Type Culture Collection (ATCC). The cells grew in RPMI 1640 supplemented with $10 \%$ fetal calf serum $1 \%$ (w/v) glutamine, $100 \mathrm{U} \cdot \mathrm{ml}^{-1}$ penicillin, $100 \mu \mathrm{g} \cdot \mathrm{ml}^{-1}$ streptomycin and $5 \mu \mathrm{g} \cdot \mathrm{ml}^{-1}$ amphotericin B. The cells were cultured in a humidified atmosphere at $37^{\circ} \mathrm{C}$ in $5 \% \mathrm{CO}_{2}$ (Da Silva et al., 2007). The macrophages were isolated from mice and kept according to the methodology described by Tseng et al. (2006).

\section{IN VITRO ASSAY CYTOTOXIC ACTIVITY}

For the in vitro cytotoxicity assay, the cells were washed with phosphate-buffered saline (PBS) free of magnesium and calcium. After PBS decantation, the cells were detached by addition of $0.025 \%$ trypsin-EDTA and PBS to a final volume of $50 \mathrm{ml}$ and centrifuged. The pellet was suspended in $10 \mathrm{ml}$ of a medium to obtain a single cell suspension. The density of viable cells was determined by Trypan blue exclusion in a hemocytometer and the preparation was diluted within a medium to yield previously determined optimal plating densities for cells.

Before the assay, $5 \times 10^{4}$ cells / well were seeded on 96-well plates and the suspension was incubated 24 hours at $37^{\circ} \mathrm{C}$ to cell attachment. After 24 hours, the cells were treated with the essential oil and sesquiterpenes. The oil was dissolved in ethanol and a serial of doubling essential oil dilution was added to five replicate wells, over the range of $600-0.6 \mu \mathrm{g} \cdot \mathrm{ml}^{-1}$ against all cell lines and macrophages. Sesquiterpens were also dissolved in ethanol and tested to five replicate wells, but over the range of $200-0.2 \mu \mathrm{g} \cdot \mathrm{ml}^{-1}$. The final concentration of ethanol in the culture medium was kept at $0.5 \%(\mathrm{v} / \mathrm{v})$ to avoid solvent toxicity. The activities of the essential oil and sesquiterpenes were considered according to the survival of $50 \%$ or less cells after an exposure time of 72 hours. The cell culture used as control received only $0.5 \%$ ethanol at final concentration.

The cytotoxicity was measured using the MTT (3-(4,5dimethylthiazol-2-yl)-2,5-diphenyltetrazolium bromide) assay. After an exposure time of 72 hours, the medium was removed and then, MTT assays were performed using the cell titer kit (Promega Corp., USA). On a 96-well plate, 20 $\mathrm{mL}$ of MTT $\left(5 \mathrm{mg} \cdot \mathrm{ml}^{-1}\right)$ in PBS was incubated with cells for 2 hours at $37^{\circ} \mathrm{C}$. After this period, the medium containing MTT was removed and $100 \mathrm{ml}$ of acidified isopropanol (0.04 mol..$^{-1} \mathrm{HCl}$ ) was added. The absorbance was measured at 570 nm using a microplate reader (Bio-Rad Laboratories, model 3550 , USA). The cell viability was expressed with respect to the absorbance of the control wells, which were considered as $100 \%$ of absorbance. The cytotoxicity is expressed as Cytotoxic Dose, the concentration of the substance inhibiting cell growth by $50 \%\left(\mathrm{CD}_{50}\right)$. Three replicate plates were used to determine the cytotoxicity of each sample (Stavri et al., 2005; Hou et al., 2006; Xiao et al., 2006; Da Silva et al., 2007).

\section{HEMOLYTIC ACTIVITY}

The hemolytic activity was assayed by incubating the essential oil or sesquiterpens with of $2 \%$ erythrocytes (sheep, bovine, horse, guinea pig, rabbit, chicken, human) washed three times with PBS (phosphate buffer saline), $\mathrm{pH} 7.2$ for 1 hour at $37^{\circ} \mathrm{C}$ in round-bottom 96-well plates. The oil was dissolved in DMSO (dimethyl sulfoxide) and a serial of double essential oil dilution was added to five replicate wells, over the range of $600-0.6 \mu \mathrm{g} \cdot \mathrm{ml}^{-1}$ against all erythrocytes. Sesquiterpens were also dissolved in ethanol and tested to five replicate wells, but over the range of $400-0.2$ $\mu \mathrm{g} \cdot \mathrm{ml}^{-1}$. The control wells received only $0.2 \%$ DMSO and its final concentration in all assays were kept constant to avoid solvent toxicity (Bhakdi et al., 1986). The hemolytic activity was expressed as the Maximum oil Concentration (or sesquiterpens) that does not cause Hemolysis (MCnH). Three replicate plates were used to determine the hemolytic activity of each sample.

\section{STATISTICAL ANALYSIS}

Data are reported as the mean \pm S.D. for at least three replicates. Statistical analysis were performed using the Student t-test, with significance level set at $\mathrm{P}<0.05$.

\section{RESULTS}

The Table 1 shows the standardization of essential oil through GC-MS. The major compounds observed in the essential oil chemical composition used in this work were: bicyclogermacrene (43.6\%), $\beta$-caryophyllene $(18.1 \%)$, $\alpha$-humulene (4.7\%), spathulenol (15.9\%), germacrene B (5.2\%), $\alpha$-humulene (4.7\%), $\alpha$-pinene (4.0\%), germacrene D (3.9\%), globulol (3.0\%), $\alpha$-muurolol (2.7\%). The oil used on this study presents a high percentage of two sesquiterpens with high cytotoxic activity: $\beta$-caryophyllene $(18.1 \%)$ and $\alpha$-humulene (4.7\%) (Duh et al., 1999; Tatman et al., 2002; Silvestre et al., 2006; Hou et al. 2006; Xiao et al., 2006).

The results of cytotoxic and hemolytic activities in the in vitro assay were summarized in Tables 2 and 3. From Table 2 , it is possible to verify that the oil extracted from $C$. sylvestris leaves and the sesquiterpens tested presented some degree of toxic activity against all the tested cells. It was also observed that the tumor cells A-549, HeLa and HT-29 were much more sensitive to the essential oil of guaçatonga $\left(\mathrm{CD}_{50}\right.$ 63.3, 60.7 and $90.6 \mu \mathrm{gg} \cdot \mathrm{ml}^{-1}$, respectively) when compared to the non tumoral Vero cells $\left(\mathrm{CD}_{50} 310.1 \mu \mathrm{g} \cdot \mathrm{ml}^{-1}\right)$ and 
Table 1 - Chemical composition of essential oil from C. sylvestris used in this work.

\begin{tabular}{lll}
\hline Compounds & $\mathrm{Rl}^{\mathrm{a}}$ & $\%$ \\
\hline$\alpha$-pinene & 938 & 4.0 \\
\hline Linalool & 1111 & 0.7 \\
\hline Pulegone & 1235 & 0.5 \\
$\alpha$-elemene & 1343 & 1.1 \\
$\alpha$-copaene & 1380 & 0.8 \\
$\beta$-bourbonene & 1388 & 0.5 \\
$\beta$-elemene & 1390 & 1.6 \\
$\beta$-caryophyllene & 1426 & 18.1 \\
$\chi \chi$-elemene & 1427 & 0.4 \\
$\beta$-gurjunene & 1430 & 0.4 \\
$\alpha$-humulene & 1456 & 4.7 \\
\hline muurolene & 1471 & 0.5 \\
\hline germacrene $D$ & 1482 & 3.9 \\
\hline bicyclogermacrene & 1498 & 43.6 \\
germacrene B & 1501 & 5.2 \\
\hline calamenene & 1521 & 2.3 \\
$\delta$-cadinene & 1524 & 0.8 \\
\hline spathulenol & 1574 & 15.9 \\
Globulol & 1582 & 3.0 \\
$\alpha$-muurolol & 1644 & 2.7 \\
\hline
\end{tabular}

a Retention indices on SE-54 column.

mice macrophages $\left(\mathrm{CD}_{50} 334.0 \mu \mathrm{g} \cdot \mathrm{m}^{-1}\right)$. The same pattern of results was observed in the tests using the compounds $\beta$-caryophyllene and $\alpha$-humulene, it means, the cells A-549, HeLa and HT-29 are more sensitive to these sesquiterpens than the Vero cells and mice macrophages.

The hemolytic activity expressed in $\mathrm{MCnH}$ (Maximal Concentration not causing Hemolysis - $\mu \mathrm{g} \cdot \mathrm{ml}^{-1}$ ) is shown in
Table 3. In all cases, erythrocytes from the different species have showed various degrees of hemolysis in the presence of both essential oil extracted from $C$. sylvestris leaves and the tested sesquiterpens. The human and bovine erythrocytes were the most sensitive to the presence of the essential oil $(\mathrm{MCnH}$ 156.2 and $158.3 \mu \mathrm{g} \cdot \mathrm{ml}^{-1}$, respectively), while the chicken erythrocytes were the less sensitive ones $(\mathrm{MCnH} 583.7$ $\mu \mathrm{g} . \mathrm{ml}^{-1}$ ). In relation to the sesquiterpens, the human, bovine and sheep erythrocytes were more sensitive (see Table 2).

\section{CONCLUSIONS}

The differential cytotoxicity of $C$. sylvestris against tumoral cells A-549, HeLa and HT-29 shows that the use of the plant against different types of cancers might present positive results, since the leaves essential oil presented low cytotoxicity against non tumoral cells (Vero cells and mice macrophages). Moreover, the tests realized using two sesquiterpens found in guaçatonga ( $\beta$-caryophyllene and $\alpha$-humulene) presented similar results to the ones verified for the plant essential oil, indicating that they might be responsible for the cytotoxic action verified. In fact, the sum up of $\beta$-caryophyllene and $\alpha$-humulene fractions of $C$. sylvestris represents a high percentage of the essential oil total composition used in this study (around 22.8\%), and it was possible to suppose that the cytotoxic effects against tumoral cells (A-549, HeLa and HT-29) observed in the action of $C$. sylvestris essential oil can be related to the presence of both substances on this plant's leaves. These sesquiterpens have already been described as cytotoxic components of other plant oils (Sibanda et al., 2004; Sylvestre et al., 2005; Hou et al., 2006; Sylvestre et al., 2006).

Table 2 - Cytotoxic activity of essential oil from leaves of $C$. sylvestris Sw, $\beta$-caryophyllene and $\alpha$-humulene in mammalians cells lines $\left(\mathrm{CD}_{50}-\mu \mathrm{g} \cdot \mathrm{ml}^{-1}\right)^{\mathrm{a}}$.

\begin{tabular}{|c|c|c|c|c|c|}
\hline & Vero & Macrophages & A-549 & HeLa & HT-29 \\
\hline Volatile oil & $310.1 \pm 1.7$ & $334.0 \pm 2.1$ & $63.3 \pm 1.1$ & $60.7 \pm 6.2$ & $90.6 \pm 8.4$ \\
\hline$\beta$-caryophyllene & $88.3 \pm 4.1$ & $107.3 \pm 9.1$ & $29.3 \pm 1.4$ & $21.8 \pm 0.9$ & $40.9 \pm 0.7$ \\
\hline$\alpha$-humulene & $129.9 \pm 0.3$ & $159.0 \pm 3.2$ & $18.9 \pm 0.4$ & $35.2 \pm 1.3$ & $24.8 \pm 1.4$ \\
\hline
\end{tabular}

average of three independent determinations; five replicates; values are mean \pm S.D.

Table 3 - Hemolytic activity of volatile oil from leaves of $C$. sylvestris Sw, $\beta$-caryophyllene and $\alpha$-humulene in mammalians erythrocytes $\left(\mathrm{MCnH} \mu \mathrm{g} \cdot \mathrm{ml}^{-1}\right)^{\mathrm{a}}$

\begin{tabular}{|c|c|c|c|c|c|c|c|}
\hline & Human & Bovine & Sheep & Horse & Guinea pig & Rabbit & Chicken \\
\hline volatile oil & $156.2 \pm 0.5$ & $158.3 \pm 0.7$ & $297.3 \pm 1.2$ & $288.1 \pm 1.3$ & $356.2 \pm 0.4$ & $350.1 \pm 0.3$ & $583.7 \pm 3.2$ \\
\hline$\beta$-caryophyllene & $96.3 \pm 1.7$ & $108.9 \pm 2.3$ & $107.6 \pm 1.7$ & $243.4 \pm 2.0$ & $328.3 \pm 0.9$ & $275.7 \pm 2.7$ & $396.6 \pm 0.6$ \\
\hline$\alpha$-humulene & $98.9 \pm 0.9$ & $99.7 \pm 0.6$ & $121.0 \pm 1.4$ & $275.4 \pm 3.7$ & $285.5 \pm 2.2$ & $338.3 \pm 1.5$ & $>400$ \\
\hline
\end{tabular}

âverage of three independent determinations; five replicates; values are mean \pm S.D. 
These results are important for the characterization of the cytotoxicity action of $C$. sylvestris, since most of the investigations related to the cytotoxic activity of guaçatonga are mainly associated to diterpens (casearins) isolated from alcoholic extracts of the plant (Morita et al., 1991; Carvalho et al., 1998; Beutler et al., 2000; Orberlies et al., 2002; Maistro et al., 2004; Mosaddick et al., 2004). The selective action of $\beta$-caryophyllene and $\alpha$-humulene in the $C$. sylvestris essential oil against tumor cells associated to casearins isolated from alcoholic extracts might help in the explanation of the anticancer activity popularly associated to the plant.

However, in opposition to the studies of Basile et al., (1990) which verified that the C. sylvestris leaves alcoholic extracts caused low acute toxicity, we concluded that the use of solutions containing high content of essential oil from leaves of guaçatonga must be carried out carefully. In fact, from Table 3 , it was possible to verify that all the tested erythrocytes were, in some degree, sensitive to the essential oil of C. sylvestris. The human and bovine erythrocytes were the most sensitive to the essential oil, indicating that, for the therapeutic use of the plant, it is necessary to observe the quantity of oil that reaches the bloodstream. Since the erythrocytes have presented the same sensitivity to both $\beta$-caryophyllene and $\alpha$-humulene, we can attribute to the sesquiterpens, at least in part, the toxic effects observed.

\section{ACKNOWLEDGEMENTS}

We would like to thank CAPES, FAPEAM and CNPq (Brazilian agencies) for the financial support.

\section{LITERATURE CITED}

Adams, R. 1995. Identification of essential oil components by chromatography/mass spectroscopy. Allured publishing, Carol Stream, IL.

Alves, T.M.A. 2000. Biological screening of Brazilian medicinal plants. Memórias do Instituto Oswaldo Cruz, 95: 367-73.

Barbosa, R.I.; Nascimento, S.P.; Amorin, P.A.F.; Silva, R.F. 2005. Notas sobre a composição arbóreo-arbustiva de uma fisionomia das savanas de Roraima, Amazônia Brasileira. Acta Botanica Brasilica, 19: 323-329.

Basile, A.C.; Sertie, J.A.; Panizza, S.; Oshiro, T.T.; Azzolini, C.A. 1990. Pharmacological assay of Casearia sylvestris. 1: Preventive anti-ulcer activity and toxicity of the leaf crude extract. Journal of Ethnopharmacology, 30: 185-197.

Beutler, J.A.; Mccall, K.L.; Herbert, K.; Herald, D.L.; Rettit, G.R.; Johnson, T.; Shoemaker, R.H.; Boyd, M.R. 2000. Novel cytotoxic diterpenes from Casearia arborea. Journal of Natural Products, 63: 657-659.

Bhakdi, S.; Mackman, N.; Nicaud, J.M.; Holland, I.B. 1986. Escherichia coli hemolysin may damage target cell membranes by generating transmembrane pores. Infection and Immunity, 52: 63-69.
Carvalho, P.R.F.; Furlan, M.; Young, M.C.M.; Kingston, D.G.I.; Bolzani, V.S. 1998. Acetylated DNA-damaging clerodane diterpenes from Casearia sylvestris. Phytochemistry, 49: 14791835.

Chiappeta, A.D. 1983. Higher plants with biological activity plants of Pernambuco. Revista do Instituto Antibiota, 21: 43-50.

Da Silva, S.L.; Figueredo, P.M.S.; Yano, T. 2006. Antibacterial and Antifungal Activities of Volatile Oils from Zanthoxylum rhoifolium leaves. Pharmaceutical Biology, 44: 657-659.

Da Silva, S.L.; Figueiredo, P.M.S.; Yano, T. 2007. Chemotherapeutic potential of the volatile oils from Zanthoxylum rhoifolium Lam leaves. European Journal of Pharmacology, 576: 180-188.

Da Silva, S.L.; Figueiredo, P.M.S.; Yano, T. 2007. Cytotoxic evaluation of essential oil from Zanthoxylum rhoifolium Lam. leaves. Acta Amazonica, 37: 281-286.

Davies, N.W. 1990. Gas chromatographic retention indices of monoterpenes and sesquiterpenes on methyl silicone and Carbouwax $20 \mathrm{M}$ phases. Journal of Chromatography A, 503: $1-24$.

Duh, C.-Y.; Wang, S.-K.; Weng, Y.-L.; Chiang, M.Y.; Dai. C.-F. 1999. Cytotoxic terpenoids from the formosan soft coral Nephthea brassica. Journal of Natural Products, 62: 1518-1521.

Esteves, I.; Souza, I.R.; Rodrigues, M.; Cardoso, L.G.V.; Santos, L.S.; Sertie, J.A.A.; Perazzo, F.F.; Lima, L.M.; Schneedorf, J.M.; Bastos, J.K.; Carvalho, J.C.T. 2005. Gastric antiulcer and antiinflammatory activities of the essential oil from Casearia sylvestris Sw. Journal of Ethnopharmacology, 101: 191-196.

Felfili, J.M.; Nogueira, P.E.; Silva Jr, M.C.; Morimon, B.S.; Delitti, W.B.C. 2002. Composição florística e fitossociológica do cerrado sentido restrito no município de Água Boa - MT. Acta Botanica Brasilica, 16: 103-112.

Hack, C.; Longhi, S.J.; Boligon, A.A.; Murari, A.B.; Pauleski, D.T. 2005. Análise fitossociológica de um fragmento de floresta estacional decidual no município de Jaguari, RS. Ciência Rural, 35: 1083-1091.

Hou, J.; Sun, T.; Hu, J.; Chen, S.; Cai, X.; Zou, G. 2006. Chemical composition, cytotoxic and antioxidant activity of the leaf essential oil of Photinia serrulata. Food Chemistry, 103: 355358.

Lorenzi, H.; Matos, F.J.A. 2002. Plantas Medicinais no Brasil: Nativas e exóticas, Instituto Plantarum de Estudos da Flora LTDA., Nova Odessa, SP, 23-24.

Maistro, E.L.; Carvalho, J.C.T.; Mantovani, M.S. 2004. Evalution of the genotoxic potential of the Casearia sylvetris extract on HTC and V79 cells by the comet assay. Toxicology In vitro, 18: 337-342.

Mans, D.R.A.; Rocha, A.B.; Schwartsmann, G. 2000. Anti-cancer drug discovery an development in Brazil: Targeted plant collection as a rational strategy to acquire candidate anticancer compounds. Oncologist, 18: 185-198.

Massada, Y. 1995. Analysis of essential oil by gas chromatography and spectrometry. J. Wiley \& Sons, NY. 
Menezes, P.R.; Schwarz, E.A.; Santos, C.A.M. 2004. In vitro antioxidant activity of species collected in Paraná. Fitoterapia, 75: 398-400.

Morita, H.; Nakayama, M.; Kojima, H.; Takeya, K.; Itokawa, H.; Schenkel, E.P.; Motidom, M. 1991. Structure and cytotoxic activity relationship of casearins, new clerodane diterpenes from Casearia sylvestris SW. Chemical and Pharmaceutical Bulletin, 39: 693-697.

Mors, W.B.; Nascimento, M.C.; Pereira, B.M.R.; Pereira N.A. 2000. Plant natural products active against snake bite — the molecular approach. Phytochemistry, 55: 627-642.

Mosaddik, M.A.; Banbury, L.; Foster, P.; Booth, R.; Markham, J.; Leach, D.; Waterman, P.G. 2004. Screening of some Australian Flacourtiaceae species for in vitro antioxidante, cytotoxic and antimicrobial activity. Phytomedicine, 11: 461-466.

Orberlies, N.W.; Burgess, J.P.; Navarro, H.A.; Pinos, R.E.; Fairchild, C.R.; Petreson, R.W.; Soejarto, D.D.; Farnsworth, N.R.; Kinghorn, A.D.; Wani, M.E. 2002. Novel bioactive clerodane diterpenoids from the leaves and twigs of Casearia sylvestris. Journal of Natural Products, 65: 95-99.

Raslan, D.S.; Jamal, C.M.; Duarte, D.S.; Borges, M.H.; De Lima, M.E. 2002. Anti-PLA 2 action test of Casearia sylvestris Sw. Bollettino Chimico Farmaceutico, 141: 457-460.

Ruppelt, B.M.; Pereira, B.E.; Gonçalves, L.C.; Pereira, N.A. 1991. Pharmacological screening of plants recommended by folks medicine as anti-snake venom-I. Analgesic and anti-inflammtory activities. Memórias do Instituto Oswaldo Cruz, 86: 203-205.

Sibanda, S.; Chigwada, G.; Poole, M.; Gwebu, E.T.; Noletto, J.A.; Schmidt, J.M.; Rea, A.I.; Setzer, W.N. 2004. Composition and bioactivity of the leaf essential oil of Heteropyxis dehniae from Zimbabwe. Journal of Ethnopharmacology, 92: 107-111.
Stavri, M.; Ford, C.H.J.; Bucar, F.; Streit, B.; Hall, M.L.; Williamson, R.T.; Mathew, K.T.; Gibbons, S. 2005. Bioactive constituents of Artemisia monosperma. Phytochemistry, 66: 233-239.

Sylvestre, M.; Legault, J.; Dufour, D.; Pichette A. 2005. Chemical composition and anticancer activity of leaf essential oil of Myrica gale L.. Phytomedicine, 12: 299-304.

Sylvestre, M.; Pichette, A.; Longtin, A.; Nagau, F.; Legault J. 2006. Essential oil analysis and anticancer activity of leaf essential oil of Croton flavens L. from Guadeloupe. Journal of Ethnopharmacology, 103: 99-102.

Tatman, D.; Mo, H. 2002. Volatile isoprenoid constituents of fruits, vegetables and herbs cumulatively suppress the proliferation of murine B16 melanoma and human HL-60 leukemia cells. Cancer Letters, 175: 129-139.

Tseng, C.-C.; Shang, H.-F.; Wang, L.-F.; Su, B.; Hsu, C.-C.; Kao, H.-Y. 2006. Antitumor and immunostimulating effects of Anoectochilus formosanus Hayata. Phytomedicine, 13: 366-370.

Taylor, L. 2002. Herbal Secrets of the Rainforest: Technical data report for guaçatonga. Sage Press, Austin, TX, 1-4.

Xiao, J.B.; Chen, X.Q.; Zhang, Y.W.; Jiang, X.Y.; Xu, M. 2006. Cytotoxicity of Marchantia convoluta leaf extracts to human liver and lung cancer cells. Brazilian Journal of Medical and Biological Research, 39: 731-738.

Recebido em 03/07/2007

Aceito em 31/01/2008 